\title{
O DIREITO ADMINISTRATIVO E SUA HISTÓRIA
}

\author{
Edmir Netto de Araújo \\ Professor Associado da Faculdade de Direito da Universidade \\ de São Paulo
}

Resumo:

O autor aborda a evolução do Direito Administrativo, desde seus primórdios até sua fase moderna, assim como as influências dos ordenamentos estrangeiros sobre o Direito Administrativo brasileiro.

Abstract:

The author's study is about the evolution of Administrative Law, from its origins until its modern phase, as well as the influences of foreign law system about Brazilian Administrative Law.

Unitermos: história do Direito Administrativo.

a. Antigüidade.

\section{a.1. Primórdios}

Costuma-se dizer que a função administrativa de qualquer Estado ou sociedade, por mais simples e primitivo que tenha sido seu ordenamento, sempre existiu, desde que o ser humano passou a viver em comunidades, mesmo com organizações rudimentares. Ou seja, a Administração seria "de todos os tempos e de todas as sociedades" ${ }^{\prime \prime}$ com funções e órgãos delegados para o exercício dessa função. ${ }^{2}$

Como, então, conciliar-se essa noção com a afirmativa, geralmente aceita, de que o Direito Administrativo é de origem recente, cujo nascimento data do

1. José Posada de Herrera. Lecciones de administración, v. I, Estabelecimiento Tipográfico, Madrid, 1843, p. 18.

2. Guido Zanobini. Corso de Diritto Amministrativo, $6^{\text {a }}$ ed., Dott. A. Giuffrè Ed., Milano, 1950. v. I. p. 31 . 
século XIX, na Europa ocidental, principalmente na França pós-revolução? Como a História responde tal indagação?

É que em todas as épocas existiram instituições administrativas, e órgãos administrativos sempre editaram regras destinadas a disciplinar e dirigir seus serviços e funcionários, mas o Direito Administrativo, como ciência, ainda não se estruturara no mundo civilizado até aquela ocasião, sendo, portanto de "origem recente" $^{3}$ Sua estruturação foi particularmente favorecida pelas idéias liberais daquela época, da instituição do Estado de Direito, mas as funções administrativas propriamente ditas sempre se exerceram continuadamente, ao contrário da legislação e da jurisdição que, por motivos vários, mas principalmente por crises políticas, muitas vezes se interrompem. ${ }^{4}$

Isto não quer dizer que não existiram e não existam, mesmo em nossos dias, países que não tenham um corpo de regras jurídicas positivas (exteriormente obrigatórias), diferentes das que regem relações de particular a particular, como ocorria na mais remota antigüidade.

A História do Direito é tributária da própria História universal: só o que até nós chegou através dos historiadores permite entender as regras dos primórdios da civilização. Sabe-se que predominava então o aspecto teológico, com os soberanos investidos em poder que se acreditava de origem divina, muitas vezes confundindo-se com funções (e mesmo figuras) sacerdotais (como ocorria em civilizações como as da Índia, Egito, Babilônia, Assíria e outras), mas já se fazendo valer as relações hierárquicas de subordinação a quem detivesse o poder. Mas é pouco o que até hoje nos chegou sobre a organização administrativa de tais sociedades antigas.

\section{a.2. Grécia antiga}

Já da cultura e civilização helênicas o mundo atual tem mais notícias. Os historiadores e jurisconsultos, através da consulta às obras principalmente de Aristóteles, obtiveram dados sobre órgãos que superintendiam e fiscalizavam o comércio em cidades que possuíam mercados importantes, que disciplinavam

3. E. Laferrière. Cours de Droit Public et Adninistratif, v. I, $5^{\mathrm{a}}$ ed., Cotillon Editeur, Librairie du Conseil d' État. Paris, 1860, p. XVIII.

4. José Cretella Jr. Direito Administrativo Brasileiro, Ed. Forense, 1983, v. I, pp. 164-165. 
atividades relativas a edifícios públicos, polícia de habitações, vias públicas, campos e bosques, escribas, carcereiros, oficiais de administração naval e militar, funcionários encarregados de comprovar e rever contas dos que manipulavam dinheiros públicos (especialmente em Atenas), formação militar e intendências (especialmente em Esparta).

Enfim, embora com normas esparsas e geralmente costumeiras, a Administração das cidades-Estados da Grécia antiga já tinha certo grau de desenvolvimento.

\section{a.3. Roma antiga}

"Gigantes do direito privado e pigmeus do direito público" Seria mesmo verdadeira essa assertiva sempre assacada contra os romanos?

É certo que os romanos não tiveram a preocupação de estruturar, como ramo separado do direito, o Direito Administrativo, dadas as circunstâncias peculiares de constituição do extraordinário império conquistado e mantido pelas armas, sua extensão e a diversificação de povos sob seu domínio, e também da predominância da mentalidade civilistica (relações jurídicas entre particulares), pois as relações de direito público, alem de variáveis em Roma de acordo com a época e a forma de Governo, eram consideradas como matéria de exercício do poder, que era quase sempre absoluto e sujeito a golpes de Estado ou revoluções.

Mas não é verdadeiro afirmar-se que os romanos descuraram da Administração, especialmente na época da República, quando o Senado desempenhava inúmeras funções administrativas, que foram sendo transferidas a órgãos especiais (censores, questores, edís, pretores). Já antes dessa época, havia a organização dos municípios, originariamente título concedido pelos romanos a certas cidades por eles conquistadas. ${ }^{5}$

Verificam-se, nas "Institutas" e no "Código" de Justiniano, mas principalmente no "Digesto" que já se tratava de noções como bens públicos de uso comum, praias e terrenos de marinha, do funcionamento de certos órgãos, com suas autoridades (edís, cônsules, procônsules, pretores) e serviços (presídios, vias e rios públicos, militares, censo, coletores de fisco, estatísticas). Os editos do pretor eram

5. Sabino Álvares-Gendin. Manual de Derecho Administrativo Español. Casa Editorial Bosch, Barcelona, 1954, p. 122. 
verdadeiros atos administrativos ordinatórios ou regulamentares, auto-executórios, pois, como os funcionários administrativos, os pretores agiam ${ }^{6}$ na qualidade de delegados do imperador. Os estudiosos costumam mesmo apontar, ${ }^{7}$ nos livros, títulos e fragmentos do "Digesto" inúmeros temas de Direito Administrativos ali tratados.

Tal organização se conservou, posteriormente, nos países europeus que estiveram sob o domínio romano, como a França e a Germânia, onde, somada a manutenção da idéia de transmissão de cargos e títulos por herança, originou-se, segundo alguns, ${ }^{8}$ a organização feudal.

\section{a.4. Idade Média. Feudalismo}

Costuma-se denominar Idade Média o período de mais de dez séculos compreendido entre a queda do Império Romano do ocidente, em $476 \mathrm{dC}$ (com a morte do imperador Teodósio, em $395 \mathrm{dC}$, havia sido dividido em romano=ocidente e bizantino=oriente) e o assim chamado Renascimento, que alguns indicam como 0 período que se seguiu ao fim do Império Bizantino, conquistado pelos turcos em Constantinopla, em 1453. Nesse período, as invasões dos povos "bárbaros" (que, não obstante, possuíam cultura própria) alteraram as organizações então existentes, causando relevantes transformações sociais, políticas e econômicas no mundo (europeu) considerado civilizado.

Do ponto de vista administrativo, costuma-se dividir esse período em fase da administração feudal, cuja organização administrativa era apenas incipiente, baseada no arbítrio e na propriedade das terras, com o poder europeu pulverizado entre os senhores feudais, que permitiam aos suseranos (pouco mais que servos) o cultivo de terras em troca de seu trabalho e sua lealdade na defesa de seus feudos e burgos que se erguiam em volta de seus castelos, e fase da administração comunal, quando os burgos medievais se organizaram, mais por volta do século XII, em comunas, com base no modelo romano dos municipios e do direito das cidades da Gália romana, com o poder exercido de forma algo mais democrática, por influência

6. Recaredo Fernandes de Velasco (Velasco Calvo). Resúmen de Derccho Administrativo. Tipografia J. Sanchez, Murcia, 1920, v. I, p. 24.

7. José Cretella Jr., por exemplo, em seu Direito Administrativo Brasileiro citado, na p. 168 , aponta cerca de 40 temas de Direilo Administrativo listados no Digesto.

8. Recaredo Fernandes de Velasco. Resúmen... cit., idem, ibidem. 
dos burgueses e das corporações de artes e ofícios, adaptando-se os usos e costumes medievais ao que diziam os textos jurídicos latinos. ${ }^{9}$

Mas ainda não se tinham condições de liberdade e democracia que pudessem favorecer a criação de um Direito que fosse, além da disciplina da estrutura administrativa, um instrumento de garantia dos cidadãos, oponivel até mesmo ao Estado. Na verdade, a partir dos primórdios da Renascença, observou-se um recrudescimento das formas governamentais absolutistas em toda a Europa (com poucas exceções), que só principiou a regredir na época (1789) da Revolução Francesa. $^{10}$

b. Idade Moderna

b.1. França: origens e evolução, as primeiras cátedras e obras do Direito Administrativo

Com as idéias liberal-democráticas difundidas pela Revolução Francesa, formou-se o clima necessário à elaboração de um Direito Administrativo como um corpo de regras disciplinadoras das estruturas administrativas, dos serviços públicos, das relações do Poder com os administrados e com os seus próprios agentes públicos, que fosse de observância obrigatória para todos, inclusive a própria (embora ainda incipiente, complicada e centralizada) ${ }^{11}$ organização administrativa do Poder.

A tripartição das funções do Estado em executivas, legislativas e judiciárias, propiciando a especialização das atividades governamentais e a relativa autonomia dos órgãos incumbidos de realizá-las, ${ }^{12}$ fundamentada na Teoria da Separação dos Poderes (L'esprit des lois, 1748, Charles Louis de Sécondat, Barón de Brède et de Montesquieu), aliada à integral sujeição do Poder Executivo ao império da lei, ou seja, às normas estatuídas pelo Poder Legislativo ${ }^{13}$ (que foi a verdadeira grande conquista da Revolução Francesa, pois o Estado a elas não se submetia) veio

9. José Cretella Jr. Curso de Direilo Administrativo, Editora Forense, 1992, pp. 152-153.

10. Diogo de Figueiredo Moreira Neto. Curso de Direito Administrativo. Ed. Forense, 1989, p. 46.

11. José Cretella Jr. Curso..., p. 154.

12. Hely Lopes Mcirelles. Direito Administrativo Brasileiro, Malheiros Editores, 1995, p. 41.

13. José Cretella Jr. Curso... cit., p. 154. 
a redundar no "Estado de Direito" caracterizado por um sistema de "freios e contrapesos" onde a autoridade de cada um dos Poderes contrabalança e equilibra a dos demais, "sob o qual pode vicejar a liberdade individual" e impedindo (ou ao menos dificultando sobremodo) o arbítrio. ${ }^{14}$

Por isso, não é sem razão que se costuma apontar como o marco inicial do Direito Administrativo uma Lei francesa do ano de 1800 (naquele excêntrico calendário francês da época, de "28 pluviose do ano VIII") que, pela primeira vez, dotou a Administração de uma organização juridicamente garantida e estável, exteriormente obrigatória a todos os administrados.

A partir de então, enfrentando-se o problema do julgamento dos atos da Administração (originariamente feito pelo Parlamento) foram criados, ao lado dos tribunais judiciários, os tribunais administrativos (contencioso administrativo) cuja instância máxima era o Conselho de Estado, os quais, como corolário lógico, passaram a elaborar de forma pretoriana direito específico da Administração. ${ }^{15}$

Contemporaneamente a esses passos evolutivos, Charles Jean Bonin publicou, em 1808, a obra Principes d'Administration Publique, na qual, pela primeira vez, se diferenciou o Direito Administrativo do Direito Constitucional. ${ }^{16}$

Mas o impulso doutrinário mais relevante na França se deu com a criação, por Luis XVIII, na época da restauração da Monarquia (1819), da cátedra de Direito Administrativo da Universidade de Paris, para cuja regência foi designado o Barão de Gérando, cuja obra "Institutes du Droit Administratif français" foi publicada em 1829. Tratava-se mais de uma laboriosa compilação de textos de leis, cuidadosamente cotejados, selecionados e sistematizados.

Com sua morte, a cátedra passou a ser regida, a partir de 1852, pelo Conselheiro de Estado Macarel, que já havia publicado, em 1842, a $1^{\text {a }}$ edição do "Cours de Administration et de Droit Administratif" também mais voltada ao direito positivo, espírito esse claramente definido em suas primeiras "Preleções" bem a gosto do "critério legalista" do Direito Administrativo francês da época. ${ }^{17}$

Ao lado de algumas outras obras iniciais, ainda pouco sistematizadas doutrinariamente, como as de E.V.Foucart (Éléments de Droit Public et

14. Manoel Gonçalves Ferreira Filho. Curso de Direito Constilucional. Ed. Saraiva, 1990, p. 116.

15. Hely Lopes Meirelles. Dircito Administrativo... cit., pp. 40 e ss.

16. Diogo de Figueiredo Moreira Neto. Curso... cit., p. 47.

17. José Cretella Jr. Direito Administrativo... cit., p. 172. 
Administratif, 1832), De Cormenin (Droit Administratif, 1840) e Adolphe Chaveau (Principes de competence et de juridiction administratives, 1841) vieram a lume as duas primeiras obras realmente doutrinárias do Direito Administrativo francês, que foram o "Cours théorique et pratique de Droit Administratif" (1847) e "Cours de Droit Public et Administratif" (1850), ambas de E. Laferrière, que depois publicaria (1896) o "Traité sur la juridiction administrative"

Ao mesmo tempo em que se procediam a estudos doutrinários, evoluía na França a Justiça Administrativa (contentieux administratif), que a cada decisão do Conselho de Estado (cujo poder de emitir decisões soberanas foi firmado pela Lei de 24 de maio de 1872), elaborava e consagrava os princípios do moderno Direito Administrativo, especialmente quanto à supremacia e à indisponibilidade do interesse público, quanto ao caráter exorbitante e derrogatório do direito comum de que são dotadas as normas de Direito Administrativo, quanto à continuidade dos serviços públicos e, finalmente, quanto aos princípios e regras que devem determinar a responsabilidade patrimonial do Estado por prejuizos causados aos particulares por atos ou omissões de seus agentes.

Aliás, foi em caso dessa última espécie, ${ }^{18}$ em sua análise pelo Tribunal de Conflitos (tribunal paritário francês, destinado a solucionar conflitos de competência entre a Justiça Administrativa e a ordem judiciária), na decisão de conflito de competência suscitado pelo Conselho de Estado, que se firmou, como se costuma dizer, a autonomia do Direito Administrativo como disciplina autônoma da Ciência do Direito.

As idéias francesas sobre Direito Administrativo e Justiça Administrativa alastraram-se, com algumas diferenças e peculiaridades locais (como, p. ex., sem o critério predominantemente legalista, ou sem a adoção da jurisdição dúplice do contencioso administrativo), principalmente por toda a Europa continental (na Inglaterra prevalece o sistema do "common law" estruturado de forma diferente) e para a América (exceto Estados Unidos da América, pelo mesmo motivo), mas também para outros paises, nos demais continentes.

18. Decisão do "Caso Blanco", Tribunal de Conflitos, Paris, $1^{\circ} .02 .1873$, voto do Conselheiro David. Marceau Long; Prosper Weil; Guy Braibant. Les grands arrêts de la jurisprudence administrative, Sirey, Paris, 1965, p. 5. 
b.2. Direito Administrativo em outros paises de origem de direito romanístico e nos do "Common Law"

\section{b.2.1. Alemanha}

A demora na unificação político-administrativa dos Estados germânicos, que só veio a ocorrer efetivamente com a Constituição de $1870,{ }^{19}$ sem dúvida prejudicou o desenvolvimento do Direito Administrativo como lei e ciência, na Alemanha.

Também as práticas vindas do regime feudal, que muitos apontam ${ }^{20}$ como de inspiração germânica, não privilegiaram os estudos administrativos em relação ao direito privado, embora se possa dizer que, por volta de 1817 (J.L.Kluber, Offentlichen recht des teutschen bundes-Direito público da federação teutônica), já se diferenciava, entre os estudiosos do direito público, o Direito Administrativo do Direito Constitucional. ${ }^{21}$

O próprio espírito germânico, voltado para o tecnicismo científicodoutrinário, em detrimento da casuística que caracterizava o Direito Administrativo francês, fez com que a evolução dessa disciplina fosse lá mais lenta e gradual. Mas realmente a falta de unidade foi fator determinante para que, só após a constituição da Confederação Germânica, o Direito Administrativo se desenvolvesse como as outras disciplinas de direito privado e direito público, ${ }^{22}$ assentado sobre a tríplice base filosófica, histórica e legislativa, apresentando então, desde as últimas décadas do século XIX, inestimável contribuição ao progresso dos estudos administrativos, influenciando decisivamente outros direitos do mundo ocidental.

Embora cronologicamente não tenha sido o precursor, pois outros autores o precederam com obras menos sistematizadas, o primeiro a sintetizar científica e doutrinariamente todo o Direito Administrativo alemão foi Paul Laband, com seu "Das staatsrecht des deutchen reichs" de 1876, obra que, traduzida por C.Gandilhon e T. Lacuire para a língua francesa, com o título de Le Droit Public de

19. José Crctella Jr. Curso... cit., p. 156.

20. Idem, ibidem, p. 152.

21. Diogo de Figueiredo Moreira Neto. Curso... cit., p. 48.

22. Lorenzo Meucci. Istituzioni di Diritto Anministrativo, Fratelli Bocca Editori, Torino, 1892, pp. $15-16$ 
I'Empire Allemand (O Direito Público do Império Alemão) divulgou, no restante da Europa latina, o estágio de desenvolvimento do Direito Administrativo alemão naquela época, publicada que foi na prestigiosa série Bibliothéque Internazionale de Droit Public, dirigida por Gaston Jèze e Max Boucard, e pela Giard \& Brière Libraires-Editeurs, em 1900.

A Laband seguiu-se Otto Mayer, em outra obra fundamental, que libertou o Direito Administrativo alemão da excessiva influência do Direito Civil e de sua vinculação ao Direito Constitucional: "Deutches Verwaltungsrecht" (Direito Administrativo Alemão), também traduzida para o francês pelo próprio autor, em 1903 (Le Droit Administratif Allemand) e para o castelhano, por Heredia \& Krotoschin (Derecho Administrativo Alemán, Ed. Depalma, Buenos Aires, 1949).

\section{b.2.2. Itália}

Embora também prejudicada pela ausência de unidade políticoadministrativa, que só ocorreu pela Lei n. 2.248, de 20.03.1865 (Lei sobre unificação administrativa do Reino da Itália), o Direito Administrativo italiano desenvolveu-se de forma peculiar, harmonizando com muita criatividade as duas influências que sofreu: o Direito Administrativo francês, da escola legalista e casuísta, e o alemão, do tecnicismo às vezes até exagerado, em feliz meio-termo. ${ }^{23}$

Costumam alguns autores situar as origens do Direito Administrativo italiano no ordenamento da região do Piemonte, então sob o jugo da França, o que indica sua influência inicial pelo direito napoleônico. A partir da já citada lei de unificação, cujos Anexos já disciplinavam a organização provincial, a segurança pública, a saúde pública, as obras públicas, o Conselho de Estado e o contencioso administrativo, ${ }^{24}$ principiou o desenvolvimento da disciplina, ainda sob influência francesa, de inspiração liberal, mas legalista e casuísta. No período do fascismo, essa inspiração foi substituída por princípios autoritários, influenciada que foi pelo Direito alemão da época. Mas após a $2^{\mathrm{a}}$ guerra mundial foi instaurada a estrutura político-administrativa parlamentar atual, e abandonada a filosofia autoritária no Direito Público italiano.

23. Vittorio Emmanuele Orlando. Il sistcma del Diritto Amministrativo, em Primo Trattato completo de Diritlo Amministrativo, Societá Editrice Libraria, Milano, 1900, p. 47.

24. Maria Sylvia Zanella Di Pietro. Direilo Administralivo, Ed. Allas, 1997, pp. 27-28. 
Quando se trata de Direito Administrativo como ciência, estruturada e sistematizada, a maioria dos autores ${ }^{25}$ reconhece, inclusive na Europa Ocidental, o pioneirismo de Gian Domenico Romagnosi, que publicou, em Parma, 1814 (2a ed. em Firenze, 1832, pela Stamperia Piatti) seu "Principii fondamentali de diritto amministrativo" a que se se seguiram, na Itália, inúmeras obras de grande importância e projeção no Direito Administrativo universal.

Desses três países, França, Itália e Alemanha, o Direito Administrativo se alastrou e desenvolveu no mundo ocidental, com influências localizadas de cada um deles ou de todos eles, como se vê no estudo dessa disciplina na Espanha, Bélgica, Suíça, Holanda, Áustria, Portugal, Grécia, etc., e nos distantes (da Europa) países da América, como Brasil, Argentina, Uruguai, Chile, Peru, Venezuela, México, etc., e mesmo no longínquo Japão, além de outros direitos.

Entretanto, por razões múltiplas, essas influências não se fizeram sentir em alguns casos, como, p.ex., os países dos blocos soviético e anglo-saxão.

\section{b.2.3. Direito Administrativo no "Common Law"}

Integram o bloco ou "sistema" do Common Law os direitos da Inglaterra, Escócia, Irlanda do Norte, Irlanda do Sul, País de Gales, Estados Unidos da América, Canadá (exceto região de Quebec) e outros, de colonização ou dominação britânica (como Austrália, África do Sul, Índia), cujos princípios não são formulados de maneira similar aos dos países de direitos de origem romanística.

Originário da Inglaterra, à época da conquista normanda, o Common Law irradiou-se para os países de influência britânica.

Embora também possua como fonte o direito escrito e legislado (Statute Law), caracteriza-se pela predominância do costume e da prática sobre a teoria e a doutrina, e, em conseqüência, pela importância do precedente judiciário: a aplicação da lei ou decisão ao caso concreto terá sempre presente o pronunciamento anterior das Cortes de Justiça sobre a matéria, o que lhe dá nítido caráter jurisprudencial e costumeiro, ou seja, "general immemorial custom of common law from time to time declared in the decisions of the Courts of Justice ${ }^{26}$ (costume geral

25. P. ex., no Brasil, José Cretella Jr. Curso... cit., p. 157; Maria Sylvia Zanella Di Pietro. Direito Administrativo... cit., p. 24; Hely Lopes Meirelles. Direito Administrativo... cit., pp. 40 e ss.; Diógenes Gasparini. Direito Administrativo, Ed. Saraiva, 1995, p. 25.

26. José Cretella Jr. Definição clássica de Blackslone, cilada $\mathrm{cm}$ Direito Administrativo Comparado, Ed. Forense, 1990, p. 141. 
e imemorial, assim declarado de época a época, por decisões das Cortes de Justiça), ou então, "a parte da lei inglesa que é criada não pelas disposições legislativas, mas por decisões judiciárias, e que devem ser localizadas nos repertórios de casos decididos. ${ }^{\text {'27 }}$

No início, a aplicação do Common Law pelos Tribunais de Westminster, com rigorismo e rigidez processual, não abrangia todas as espécies de obrigações, dificultava a obtenção de provas e apuração da verdade, e tal rigidez impedia aos juízes a adaptação do precedente a circunstâncias especiais do caso concreto, resultando muitas vezes em "vitória vazia" ou seja, ineficácia do processo para o objetivo visado. Assim, começou a ser desenvolvida paralelamente a Equity, destinada a fazer justiça além dos precedentes e sua interpretação rígida, para satisfazer as falhas na satisfação da pretensão dos litigantes, impedindo o summum jus, summa injuria. A Chancelaria transformou-se no verdadeiro Tribunal da Equity, funcionando paralelamente a Westminster (Common Law), até os Judicature Acts de 1873 e 1875, que os fundiu.

A partir destes Judicature Acts, a observância dos precedentes passou a ser expressa e de hierarquia mais sistêmica: precedente da House of Lords é obrigatório para todas as jurisdições; da Court of Appeal, para todas as jurisdições inferiores, inclusive para a própria Court of Appeal, da High Court of Justice, para todas as jurisdições inferiores e locais, considerando-se a composição (Queen's Bench, King's Bench, Chancelary, Family Division, etc.) da referida Corte, sendo a regra do precedente também obrigatória nos processos da Equity.

As decisões dos tribunais ingleses são publicadas em repositórios, depois de uma triagem que determina o que pode servir de precedente, sendo os mais importantes: Year Book, English Reports (os mais antigos), All England Law Reports, Halbury Laws of England e Weekly Law Reports.

Quanto ao Direito Administrativo, em si, os ingleses até algum tempo atrás negavam sua existência na Inglaterra, ao passo que nos Estados Unidos colocava-se tal matéria fora da Ciência do Direito (mais na Ciência da Administração Pública, ramo da Ciência Política).

Entre os britânicos, tal fato deveu-se, principalmente, ${ }^{28}$ a Albert Venn Dicey (cuja obra, Lectures introdutory to the study of law of the Constitution, foi

27. Frederic Pollock. Essays on jurisprudence and ethics, 1882, cap. IV.

28. Maria Sylvia Zanella Di Pietro. Dircito Administrativo... cit, p. 30. 
publicada em 1885). que afirmava ser a Administração submetida ao controle judicial em igualdade de condições com os particulares, e que a submissão daquela aos princípios da "rule of law" (império da lei) e do "due process of law" (devido processo legal), com tal característica, não diferente do processo entre particulares, impediria a existência do Direito Administrativo, tal como se entendia na França, na Inglaterra. O Estado não poderia ter prerrogativas administrativas e processuais, como no Direito francês, não tinha a chamada "puissance publique" (que iria fundamentar a prática dos "atos de império"), e deveria litigar em igualdade de condições com os particulares: tudo como, dizia ele, ocorria na Inglaterra, e por isso negava até mesmo a possibilidade da existência autônoma de um Direito Administrativo.

Dizem os autores, ${ }^{29}$ entretanto, que se tratava de equívoco de interpretação de Dicey à obra de Tocqueville, acreditando significar o Direito Administrativo "arbitrário administrativo" contrapondo-se ao "rule of law" inglês, quando, na verdade, o Direito Administrativo é o conjunto de regras especiais relativas ao funcionamento dos serviços públicos, que realmente existem, na Inglaterra, como em qualquer país civilizado. ${ }^{30} \mathrm{Na}$ verdade, mesmo os autores ingleses, ${ }^{31}$ no início deste século, admitem esse equívoco, interpretando o pensamento de Dicey, para quem "rule of law" significa supremacia do direito comum, sem privilégios, prerrogativas ou poderes discricionários aos agentes públicos, mesma jurisdição para todos, Estado e particulares, e existência de um direito comum, tal como interpretado pelos Tribunais de Common Lawe Equity.

Os mesmos princípios gerais se aplicam a todas as várias repartições governamentais, sem nítida distinção entre Direito Privado ou Civil e Direito Administrativo, mas não pensam mais ${ }^{32}$ em não haver um real sistema de Direito Administrativo: embora desenvolvido de maneira diversa que o da Europa continental, existe o Direito Administrativo, mas sem autonomia em relação ao Direito Constitucional inglês (edição de 1915 da citada obra de Dicey).

29. José Cretella Jr. Direito Administrativo Brasilciro... cit., p. 181.

30. Gaston Jèze. Les principes génćraux du Droil Administratif, Giard \& Brière Ed., Paris, 1914 v. I, nota 1 .

31. J.F.Garner. Administrative Law. Edição de 1974, Butherworths, London, p.1- a primcira edição foi de 1929 .

32. H.W.R.Wadc. Administrative Law, Clarendon Press, Oxford, 1971, prefácio. 
Há que se recordar, também, o objetivo da "separação de poderes" da França (retirar do Judiciário o poder de julgar a Administração), não tão nítida na Inglaterra, na qual se pretendia não permitir poderes excessivos ao Executivo.

Com efeito, no Common Law, o desenvolvimento de um "regime jurídico administrativo" seria diferente dos sistemas romanísticos: base jurisprudencial predominante sobre a teórica ou doutrinária; relação da Administração com seus agentes mais próxima ao que designamos Direito do Trabalho, direito comum; a auto-executoriedade é exceção (summary power), o que prevalece é a execução titulada típica do Direito Privado. E, curiosamente para quem defende tanta igualdade entre Estado e cidadão, até a pouco tempo vigia, na Inglaterra, o princípio da irresponsabilidade patrimonial da Coroa ("the king can do no wrong"- o rei não pode errar) por atos de seus agentes (atualmente mitigado) e da responsabilidade do agente público equiparada à do empregado no Direito Privado. ${ }^{33}$

O princípio da submissão do Poder Público ao império da lei não acarreta necessariamente a existência de um Direito Administrativo, como um direito especial da Administração. Mas o fato de, no Common Law, a Administração utilizar esquemas privatísticos em suas relações normais com os particulares e seus próprios agentes, e de não possuir prerrogativas (especialmente na área judiciária), também não determina, necessariamente, sua inexistência, ${ }^{34}$ embora menos desenvolvido, como já dissemos, que no sistema romanístico.

Há fatos e atos, mesmo nos países britânicos, que deixam clara a prevalência do interesse público sobre interesses ou mesmo direitos dos particulares, como desapropriações, atos do poder de polícia, ruptura de contratos prejudiciais ao Estado, ${ }^{35}$ auto-executoriedade de regras de trânsito, etc., e esta prevalência é a pedra angular do Direito Administrativo.

Na Inglaterra e nos Estados Unidos reconhece-se, hoje, a existência de um conjunto de regras administrativas, embora subsistindo a equivalência de posições (horizontalidade) entre a Administração e o cidadão, especialmente perante o Judiciário. Em decorrência desta filosofia privatística, nesses países proliferam colegiados, comissões e organismos "quase" jurisdicionais (Boards, Comissions,

33. José Cretclla Jr. Direito Administrativo Comparado... cit., p. 159.

34. Jean Rivero. Droit Administratif, Dalloz, Paris, 1980, pp. 16-17.

35. Maria Sylvia Zanella Di Pietro. Direito Administrativo... cit., p. 35. 
Agencies, etc.) para examinar questões e litígios de ordem administrativa, e mesmo para "filtrar" o acesso do cidadão ao Judiciário, evitando o congestionamento deste.

Portanto, é de horizontalidade a atuação da Administração (mesmo patamar), típica do Direito Privado, ao contrário da verticalidade (puissance publique) do Direito Administrativo romanístico, no qual a Administração se coloca em posição de supremacia nas relações com os administrados e mesmo com seus próprios agentes, quando age utilizando as prerrogativas de autoridade pública. No Common Law a responsabilidade dos agentes públicos é pessoal, sem prerrogativas, regida pelo direito comum, mas nos Estados Unidos se aproxima mais da teoria do risco. A execução é titulada, a auto-executoriedade é exceção. $\mathrm{O}$ regime jurídico "administrativo" oferece maior prestígio às regras jurisprudenciais que à lei, à doutrina e mesmo codificações que, nos Estados Unidos, são mais importantes que na Inglaterra.

A irradiação do Common Law para os Estados Unidos ocorreu de forma peculiar às condições locais, sendo o Direito americano intermédio em relação ao Direito romanístico. Isto aconteceu porque são grandes as diferenças entre os dois países, a começar pelo próprio regime de governo e sua forma de Estado: a Inglaterra é um país unitário, monarquia parlamentar, de jurisdição fortemente centralizada; os Estados Unidos são república federativa presidencialista, jurisdição descentralizada, com o bom senso substituindo a rigidez exagerada da jurisdição inglesa.

Além disto, nos Estados Unidos existem direito federal, estadual e municipal, inexistentes na Inglaterra; a constituição americana é escrita e existem mais leis escritas, o que não ocorre no sistema britânico. Embora trazendo a marca do Common Law, o Direito americano se aproxima do sistema romanístico em vários pontos, inclusive por influência francesa.

Especificamente no Direito Administrativo (como relações entre governantes e governados), na Inglaterra a regra é a normatização local e peculiar, e nos Estados Unidos a matéria é da competência dos estados e dos condados/municípios, estando atualmente em plena evolução o assim chamado "Direito municipal" Mas há regras federais regulando os serviços públicos dessa esfera, na área administrativa.

Diz-se, atualmente, nos Estados Unidos, que o Direito Administrativo regula e controla a conduta das autoridades do Poder Executivo do Presidente, dos Governadores dos estados, dos membros do Gabinete, dos Ministros, dos chefes de 
departamentos, e das demais autoridades federais, estaduais e municipais, além de regular as juntas, como a Comissão de Comércio Interestadual, as comissões estaduais de utilidade pública, as autoridades que concedem licenças e muitas outras autoridades administrativas que dirigem a vida econômica e política americana. Um dos principais objetivos do Direito Administrativo é estabelecer princípios que orientem o administrador e leis que controlem os impulsos e caprichos das autoridades, a fim de mantê-los no cumprimento do dever sem lhes tirar a iniciativa. Sua função principal é dupla: capacitar o cidadão a vigiar e controlar as autoridades públicas, e os indivíduos prejudicados por uma ação fora da lei, a desagravar-se. ${ }^{36}$

A maior parte desses estatutos, que dão poderes e deveres a autoridades, mas também certa liberdade de ação, provém dos estados e municípios, ${ }^{37}$ e as controvérsias dentro da organização administrativa fazem parte mais da Teoria Geral do Estado e planos/programas políticos do que propriamente Direito Administrativo. Este, em conceito elevado, baseia-se na proteção dada pela lei ao público e a cada cidadão contra o abuso de poder por parte da autoridade, princípio encontrável tanto no Direito americano como no inglês, há muitos séculos. $^{38}$

Outra característica do Common Law, na Inglaterra, é a ausência de uma literatura peculiar ao Direito Administrativo, tanto que vários autores alemães, como Rudolf Gneist (Das englische verwaltungsrecht, de 1898 Direito Administrativo inglês) e outros, focalizaram este aspecto do Direito britânico, preenchendo essa lacuna. ${ }^{39}$ Mas pode-se considerar J.F. Garner (Administrative Law citado, cuja primeira edição é de 1929) como precursor dos estudos administrativos britânicos mais atuais.

Já nos Estados Unidos é mais prolífica a literatura sobre a matéria, sendo comumente apontada a obra ${ }^{40}$ de Frank J. Goodnow como a pioneira dos

36. Louis L.Jaffe, Administrative Law ("Direito Administrativo"), em Talks on American Law ("Aspectos do Direito americano"), coordenação de Harold.J. Berman, Random House Inc., New York, 1961, tradução de Janine Y.R.Peres e Arlete P.Centurion, Ed. Forense, 1963, pp. 90 e 91.

37. Idem, ibidem, p. 93.

38. Idem, ibidem, p. 98.

39. José Cretella Jr. Direito Administrativo Brasileiro... cit., p. 182.

40. Frank J.Goodnow. Comparative Administrative Law, New York-London, 1893; e Principles of Administrative Law of United States, New York-London, 1905. 
estudos sistematizados do Direito Administrativo americano, e uma das mais completas dessa disciplina.

\section{b.3. Evolução do Direito Administrativo no Brasil}

Poucos são os autores que oferecem alguma menção ao Direito Administrativo do Brasil-colônia, e mesmo dos primeiros anos do Brasil-império. $\mathrm{Na}$ verdade, a literatura administrativa desse período é escassa mesmo nos países europeus, pois, como se viu, o Direito Administrativo começou a ser elaborado como ciência, doutrina e mesmo um corpo de regras especiais para a estrutura da Administração e suas relações com seus agentes e com os administrados, somente em fins do século XVIII, tendo como ponto de referência a época da Revolução Francesa.

Mas, no que concerne à Administração, sua estrutura e serviços públicos, existem algumas referências, mais históricas que jurídicas, da era colonial.

Os donatários das Capitanias hereditárias eram inicialmente detentores de poderes absolutos outorgados pelo rei de Portugal, nas suas circunscrições territoriais. Mesmo na época dos Governos Gerais, embora houvesse certa repartição de atribuições entre o Governador Geral, o Provedor Mór e o Ouvidor Geral, o primeiro, que até teve, em certa ocasião, o título de "vice-rei" concentrava, na prática, os poderes, desempenhando, como o Capitão Mór das Capitanias, as funções de legislação, administração e justiça. ${ }^{41}$

Era a época das Ordenações do Reino (Manuelinas, Afonsinas, Filipinas) da implantação, inclusive em Portugal, do estamento burocrático, superando a noção feudal de suserania, e da centralização da soberania, com a codificação das leis gerais, fazendo dos reinos ibéricos os primeiros a apresentar governo central estruturado, distribuindo os agentes por carreira e hierarquia. ${ }^{42} \mathrm{~A}$ Justiça, nas Capitanias, cabia com exclusividade ao Capitão-donatário, que nomeava o Ouvidor, seu representante nas coisas da Justiça, e nomeava os "homens

41. Maria Sylvia Zanclla Di Pictro. Direito Administrativo... cit., p. 37.

42. Raymundo Faoro. Os donos do poder (Formação do patronato político brasileiro), Ed. Globo, 1958. pp. 30-33; Hélio de Alcântara Avellar. História Administrativa do Brasil, v. 1 - Preliminares Européias, FUNCEP, Brasília, 1984, pp. 74-75. 
bons" (à imagem dos "Concelhos dos homens bons" de Portugal), que deveriam indicar a ele, para nomeação, os juízes ordinários. ${ }^{43}$

Para fixar o imperium português sobre as colônias, inclusive o Brasil, e exercer sobre elas o controle administrativo, criou-se, em 1642, o Conselho Ultramarino, ao qual a Administração do Governo Geral se reportaria, e que era encarregado de orientar a reconstrução politico-administrativa das colônias, com jurisdição para todos os negócios destas, exceto os do Conselho da Fazenda e da Mesa da Consciência e Ordens (assuntos religiosos). Através de resposta a consultas e de provimentos, dirigia, da Metrópole, toda a vida administrativa da colônia, que, não obstante teve restaurado, com jurisdição específica descentralizada, o Tribunal da Relação, na Bahia. ${ }^{44}$

Tivemos, ainda, a partir do século XVIII, o retorno ao absolutismo na Europa, que, para o Brasil, só foi mitigado com a vinda de D. João VI. Ainda aconteceu, de 1630 a 1654, no nordeste, o episódio do domínio holandês, sob Maurício de Nassau, cuja característica foi o planejamento administrativo e o estabelecimento de vários setores da Administração. ${ }^{45}$

Entretanto, em toda a época do Brasil-colônia, pelas próprias circunstâncias, repetindo o que acontecia na Europa, não havia condições institucionais ou políticas para o surgimento de um Direito Administrativo, embora já se notasse o surgimento de certas instituições, como os municípios, de inspiração portuguesa e romana. O "Estado de Direito" estava ainda longe de ser concebido.

Já na época do Império (1822/1889), quase coincidente com a criação da cátedra de Direito Administrativo da Universidade de Paris (1819), embora já existente uma divisão do poder entre Legislativo, Judiciário, Executivo e Poder Moderador (estes dois últimos acumulados pelo Imperador), ainda se tratava de uma monarquia absolutista, porque, embora mitigado o poder absoluto, este podia ser exercido discricionariamente pelo Imperador, se esta fosse sua vontade. Mas já havia

43. Vicente Costa Santos Tapajós. História Administrativa do Brasil, v. 2, A politica administrativa de D. João III, Ed. Universidade de Brasília-FUNCEP, 1983, p. 36.

44. João Alfredo Libânio Guedes. História Administrativa do Brasil, v. 4, Da restauração a $D$. João V, FUNCEP, 1984, pp. 31-42.

45. Joaquim Ribeiro. História Administrativa do Brasil, v. 3, A União Ibérica e a Administração do Brasil Holandês, Ed. Universidade de Brasilia-FUNCEP, 1983, pp. 300-301. 
uma organização estável da Administração, apesar de predominante a aplicação do Direito Privado pelo "Conselho de Estado" 46

A partir da metade do século XIX, rendendo-se à influência francesa que, de resto, predominava em nossa cultura, e era incentivada pelo próprio imperador D. Pedro II, o Direito Administrativo passa a ser incluído nos programas das Faculdades de Direito (Decreto n. 608, de 16.08.1851), tendo sido instalada a cátedra da disciplina na Faculdade de Direito da Universidade de São Paulo em 1856, cujo primeiro regente foi Francisco Maria de Souza Furtado de Mendonça. Praticamente é o batismo do Direito Administrativo brasileiro, já acompanhando as modernas tendências européias e, de certa forma, preparando o terreno para a era republicana.

São dessa época os primeiros trabalhos doutrinários de Direito Administrativo, como os de Vicente Pereira do Rêgo (Elementos do Direito Administrativo Brasileiro, Recife, 1857); Prudêncio Giraldes Tavares da Veiga Cabral (Direito Administrativo Brasileiro, Rio, 1859); Visconde do Uruguai (Ensaios sobre o Direito Administrativo Brasileiro, Rio, 1862); Francisco Maria de Souza Furtado de Mendonça (Excerto do Direito Administrativo Pátrio, SP، 1865); José Rubino de Oliveira (Epítome do Direito Administrativo Brasileiro, SP, 1865); José Antonio Joaquim Ribas, o Conselheiro Ribas (Direito Administrativo Brasileiro, SP, 1866); José Higino Duarte Pereira (Lições de Direito Administrativo, $\mathrm{SP})$. Dessas, a mais significativa obra, segundo alguns, ${ }^{47}$ é a do Visconde do Uruguai.

O Direito Administrativo brasileiro, na verdade, começa a tomar seus contornos atuais com a República, a partir de 1889. Nosso direito, com influências européias (França, Itália) e mesmo norte-americanas, adapta-se ao fato de ter sido constituída uma república federativa presidencialista, nos moldes dos Estados Unidos, com o monopólio jurisdicional do Judiciário (jurisdição una norteamericana), que levou à supressão da jurisdição administrativa, já então pouco existente no Brasil. ${ }^{48}$ Entretanto, face às peculiaridades, a elaboração doutrinária

46. Maria Sylvia Zanella Di Pietro. Direito Administralivo... cit.. p. 37.

47. Diogo de Figueiredo Moreira Neto. Curso... cit., p. 55.

48. Edmir Netto de Araújo. Responsabilidade do Estado por ato jurisdicional, Ed. Revista dos Tribunais, 1981, pp. 74-75. 
dessa época, mais ou menos até a Constituição de 1934 era, senão pobre, algo titubeante. ${ }^{49}$

Há, nessa época, certa influência do Direito Civil no Direito Administrativo brasileiro, tomando-se de empréstimo os institutos civis, adaptandoos ao Direito Público, em clara predominância da base do Direito italiano, de um lado, e do Direito americano que, afinal, era o nosso modelo federativo, ${ }^{50}$ principiando também, após 1930, o prestígio da doutrina alemã.

Autores mais significativos do período: Augusto Olimpio Viveiros de Castro (Tratado de Ciência da Administração e Direito Administrativo, Rio, 1906); Alcides Cruz (Noções de Direito Administrativo Brasileiro, Porto Alegre, 1910); Carlos Porto Carreiro (Lições de Direito Administrativo, Rio, 1918); Manuel Porfírio de Oliveira Santos (Direito Administrativo e Ciência da Administração, Rio, 1919); José Joaquim Cardoso de Melo Neto (Preleções do Direito Administrativo, SP 1923); Aarão Reis (Direito Administrativo Brasileiro, Rio, 1923) e, ao final desse período, dois autores que também se incluem no subsequente, Mário Masagão (Conceito de Direito Administrativo, SP, 1926) e Rui Cirne Lima (Princípios do Direito Administrativo Brasileiro, Porto Alegre, 1937).

Inaugura-se, daí em diante, o que poderíamos chamar de fase atual do Direito Administrativo brasileiro, que alcança nossos dias com uma elaboração doutrinária em grande parte própria e original, pois as influências estrangeiras, cada vez mais setorizadas, passam a servir mais como subsídios para as soluções nitidamente brasileiras, em relação aos grandes temas administrativos: atos e contratos administrativos, Itália e Alemanha; responsabilidade do Estado e dos funcionários, França; Justiça administrativa, Estados Unidos; concessões, França, e assim por diante.

Inicialmente com Masagão e Cirne Lima, depois com Matos de Vasconcelos, Tito Prates da Fonseca, Guimarães Menegale e Themístocles Brandão Cavalcanti, e logo a seguir uma nova geração, onde brilhavam (e muitos ainda brilham) nomes como Caio Tácito, Oswaldo Aranha Bandeira de Mello, José Cretella Jr., Olavo Bilac Pinto, Hely Lopes Meirelles, José de Aguiar Dias, ManoeI de Oliveira Franco Sobrinho, Fernando Andrade Oliveira, Lafayette Pondé e outros, até os expoentes de nossos dias, tais como Maria Sylvia Zanella Di Pietro,

49. Maria Sylvia Zanella Di Pietro. Direito Administrativo... cit., pp. 37-38.

50. Hely Lopes Meirelles. Direito Administrativo... cit., pp. 40 e ss. 
Odette Medauar, Celso Antonio Bandeira de Mello, Adilson Abreu Dallari, Lúcia Valle Figueiredo, Diógenes Gasparini, Diogo de Figueiredo Moreira Neto, Sérgio de Andréa Ferreira, Sérgio Ferraz, Carlos Reis Velloso, Pedro Paulo de Almeida Dutra, Paulo Neves Carvalho, Valmir Pontes Filho, e tantos outros, com tantas e tão variadas $^{51}$ obras sistemáticas e monografias, que preferimos não citá-las especificadamente, pois, em grande parte, compreendem obras ainda atuais e em uso e consulta pelos cultores da matéria.

São Paulo, janeiro de 2000.

51. José Cretella Jr., por exemplo, publicou mais de cem obras e artigos. 